\title{
Biocontrol Efficacy of Trichoderma spp. Against Phytophthora Blight of Pepper
}

\author{
Ram Devi Timila and Shrinkhala Manandhar \\ Plant Pathology Division, Nepal Agricultural Research Council(NARC), Khumaltar, Lalitpur, Nepal \\ Corresponding author's email: rtimila@gmail.com
}

Received on: 21 June 2019, Revised on: 15 August 2019, Accepted on: 4 January 2020

\begin{abstract}
Phytophthora blight (PB) caused by Phytophthora capsici Leonian is an economically important disease of pepper in Nepal. Experiments were conducted in epiphytotic conditions at Luvu, Lalitpur where severe outbreak of PB used to occur. The experiment was designed in randomized complete block with three replications. Three isolates of Trichoderma harzianum viz, T. harzianum (T22), T. harzianum (T69), and T. harzianum and one isolate of T. asperellum, were tested for their efficacy under the field conditions compared to chemical fungicides, copper oxychloride and fluazinam for two years, 2012 and 2013. In the first year experiment, the effect of all three isolates of $T$. harzianum was significantly different from the control. $T$. harzianum (T69), the local isolate was found better in reducing PB incidence and severity by $46 \%$ and $27 \%$ respectively during 2012. Similarly, in 2013 PB incidence and severity were reduced by $36 \%$ and $42 \%$ respectively and yield increased by $57 \%$ over control. However the chemical fungicides, fluazinam was the best treatment in reducing PB severity with increased yield by $70 \%$ followed by copper oxychloride that increased yield by $62 \%$ over control during 2013 . There was no significant difference in efficacy of T69 and tested chemical fungicides. Hence, the use of Trichoderma harzianum (T69) could be one of the environmentally sound tools for the integrated management of Phytophthora blight.
\end{abstract}

Keywords: : Phytophthora blight, Severity and Trichoderma

\section{Introduction}

Pepper (Capsicum annuum L.) is an economically important vegetable as well as spice crop in Nepal. Phytophthora blight caused by an oomycete pathogen, Phytophthora capsici Leonian is a widespread destructive disease in pepper affecting the production as well as quality of the produce (Barksdale et al., 1984). $P$. capsici has a wide host range with more than 50 plant species including those belonging to Cucurbitaceae, Leguminosae, and Solanaceae (Hausbeck and Lamour, 2004; Hwang and Kim, 1995; Tian and Babadoost, 2004). Foliar blight, fruit rot and crown/root rot are the three phases of Phytophthora blight disease. Among them crown/root rot is the most devastating phase which could cause the complete loss of the crop. Heavy rainfall, saturated soils, and warm temperatures favor disease development. Phytophthora blight usually starts on the plants in low and poorly drained areas of a field, especially after excessive rain. Soil-borne nature, high inoculum pressure, aggressiveness of the pathogen, high precipitation during cropping period, existence of physiological races, increased resistance of the pathogen to chemical fungicides and susceptibility of the crop are the factors that cause epidemic outbreak of disease in the field. 
In Nepal, this disease is prevalent in most of the pepper cultivating areas and has appeared in devastating form causing huge loss. So, pepper cultivation is very limited or reduced. Among the available management measures, cultural control was considered to be the primary method of control, but it might not be successful in reducing loss at high soil moisture conditions. Crop rotation is another option, which may also not be useful enough in the areas where intensive cropping of vegetable crops and small land holdings of the farmers exist. So, relying on only one control method may not manage this disease effectively (Johnston, 1997).

Now a days, the use of chemical pesticides is of great concerns to the consumers because of residual effects and health hazards. So, emphasis of the production of most of the agricultural crops has shifted from chemical pesticides to organic production by using natural resources and indigenous knowledge of the farming communities. In this regard, biological control is one of the options. Trichoderma spp. have received considerable attention as potential biological control agents against a wide range of soil-borne plant pathogenic fungi. They are free-living antagonistic fungi which are common in soil and root ecosystems. They reduce growth and survival of pathogen and infections caused by pathogens through competition, antibiosis, mycoparasitism, hyphal interactions, and enzyme secretion. Trichoderma are highly ecologically successful fungi and have been used increasingly in commercial agriculture (Knudsen and Dandurand, 2014). Success of biological control agents depends on the compatibility with other disease management systems. At the same time, their efficacy may vary with location, environment and soil conditions. T. harzianum and T. hamatum have been found as the natural enemies of $P$. capsici (CABI, 2001) and first one is known to cause systemic induced resistance against $P$. capsici (Ahmed et al., 2000).

Considering the importance of these different approaches that could help in reducing chemical pesticides use, this study was conducted using various Trichoderma spp. for the control of Phytophthora blight disease of pepper. Efforts have been made to find the efficacy of different Trichoderma spp. compared to chemical fungicide. Emphasis has been given for the isolates of T. harzianum that could be used as biological control agents for integrated management of Phytophthora blight disease of pepper.

\section{Materials And Methods}

First, laboratory experiments were conducted to evaluate efficacy of Trichoderma isolates against Phytophthora capsici. The experiment was conducted in the laboratory of Plant Pathology Division at Khumaltar following dual culture technique, in which five $\mathrm{mm}$ disc size of both Trichoderma and $P$. capsici from 5-6 days old pure culture were simultaneously inoculated in opposite sides of V8-agar medium plates in about $3 \mathrm{~cm}$ distance and incubated at $24-26^{\circ} \mathrm{C}$ for 5 days. The evaluation of biological control efficacy of Trichoderma isolates were done based on over growth, zone of inhibition formation and competitive growth (PPD, 2012)

Secondly, the isolates of Trichoderma were also evaluated under inoculated conditions in screenhouse, using the seedlings of Kathmandu local variety (PPD, 2012). Sporangial and mycelial suspension was inoculated in sterilized soil at the ratio of 1:10 v/wt. Siultaneously, Trichoderma isolates multiplied in rice husk were amended in pathogen inoculated soil at the ratio of 1:20 v/v. Then 5-week-old seedlings were transplated two days after soil inoculation. Disease was scored for 7 weeks using 1-5 scale as mentioned below in field evaluation

Thirdly, the results were also verified under field conditions, For field evaluation, experiments were conducted during April to August, 2012 and 2013 in naturally infested farmer's field at Luvu, Lalitpur to evaluate Trichoderma spp. which had showed the potential biocontrol characteristics in in vitro tests and seedling assay (Table 1). Three isolates of Trichoderma harzianum and one $T$. asperellum were included in the experiment. The fungicides fluazinam (Fluazinan) and copper oxychloride (Curex) were also included for comparison. Seedlings of hot pepper (Kathmandu local variety) were raised at the screenhouse of Plant Pathology Division,Khumaltar. Randomized complete block design with three replications was adopted. The plot size was 4.5 square meter. Each replication contained three rows ( $2 \mathrm{~m}$ length each), each with 8 plants. Plant to plant and row to row distances were maintained in 25 and $50 \mathrm{~cm}$, respectively. Compost at the rate of 15 ton/ha and recommended dose of chemical fertilizer (NPK, 100:60:60 per hecter) were applied. Six weeks old seedlings were transplanted. The mentioned fungicidal treatments and Trichoderma spp. (multiplied 
in rice husk) were applied during transplanting. Their doses, rate applied and application methods are given in table 2 and 3. Other agronomical practices were provided as per need. Observation was done for 8 weeks in fortnightly interval after appearance of disease symptoms. Disease severity was assessed using 1-5 scale, modified from Ristaino (1991), where 1=no disease and 5 for death of the plant. Yield was taken at harvest, however, in the first year of the experiment it could not be taken due to the damage of the most of the plants by heavy rainfall and hail stone immediately after transplanting. The data was based on terminal disease incidence and disease severity at 8 weeks after transplanting. Treatments effect was analyzed with Mstat C statistical package. Arcsine or square root transformation of data was done before analysis.

\section{Results And Discussion}

The results presented in table 1 shows potential biocontrol characteristics of the isolates of T. harzianum against $P$. capsici in dual culture in in vitro either with masking effects (overgrowth) or with formation of zone of inhibition. The isolates, Th and T22 formed zone of inhibition of 0.4 and $0.45 \mathrm{~cm}$ sized and T69 showed masking effect with over growth on P. capsici. These showed to have biocontrol efficacy against P. capsici. Seedling assay under inoculated conditions at screenhouse also showed significantly lower mean disease severity in .T. harzianum applied treatments compared to control. The effect of the isolates, Th, T22 and T69 on PB severity were statistically different from control., whereas, those isolates did not show statistical difference from control in disease incidence percent

In the field conditions, disease appeared two weeks after transplanting. Crown/root rot incidence and foliar blight severity progressed beyond 8 weeks after seedling transplanting. During 2012, significant difference in mean disease incidence was observed among the treatments. The effect of all three $T$. harzianum isolates and fluazinam on disease incidence (crown/root rot) was statistically different from control (Table 2). It was observed that $T$. asperellum was not effective against crown/root rot phase of PB. In case of foliar blight severity, lesser disease severity was found in all treatments than in control, however, the effects were not significantly different (Table 2 ). effect of only T69 isolate was significantly different from control for disease incidence as well as foliar blight severity. Reduction in disease incidence and severity was seen as 36 and 54\%, respectively. The effects of fluazinam and copper oxychloride were also significanltly different from control. Yield data at harvest showed that, among the Trichoderma isolates, only T69 isolate showed significantly increased yield as compared to control. Highest yield was recorded in fluazinam-treated plot followed by copper oxychloride, which were significantly different from control.(Figure 1).

In the present study, T. asperellum was not found effective against Phytophthora blight but Segarra et al. (2013) reported reduced PB disease by $71 \%$ due to $T$. asperellum. However, the isolate was different because we have used our own local isolate. Similarly, in vitro capacity of T. harzianum to inhibit mycelia growth and disintegration of $P$. capsici hyphae have been observed by Ezziyyani et al. (2007) under scanning electron microscopy. In present study the biocontrol efficacy shown by $T$. harzianum could be due to the same mechanism as observed by Ezziyyani et al (2007). In addition, efficacy of $T$. harzianum isolates were not consistent but reduction ofdisease incidence and severity were obvious. It could be due to the environmental influences and the survival and multiplication of the biological control agents that limit their efficacy as mentioned by Khetan (2001). Furthermore, successful hyphal growth and proliferation of the agent in soil or the rhizosphere are critical attributes of the biocontrol fungus that has to compete with rhizosphere microbial communities that determine the success of a biocontrol agent (Knudsen and Dandurant, 2014).

Similarly, the result showed that both fungicides, copper oxychloride (Curex) and fluazinam were highly effective, but copper oxychloride is more safer than fluazinam from organic point of view because copper oxychloride is listed under organic pesticides (Staff, 2018). At the same time, copper oxychloride is compatible to $T$. harzianum in their effect. In in vitro test only $3 \%$ growth of T.harzianum was inhibited by copper oxychloride (PPD, 2014) Hence, for the management of Phytophthora blight, it is possible to use copper oxychloride and T. harzianum in combination.

During 2013, among T. harzianum isolates, the 
Table 1. Response of different Trichoderma spp. on dual culture and in seedling assay against Phytophthora capsici (Source: PPD 2012

\begin{tabular}{|l|l|l|l|l|}
\hline \multirow{2}{*}{ Trichoderma spp. } & \multirow{2}{*}{ Source } & $\begin{array}{l}\text { Reaction in dual } \\
\text { culture }\end{array}$ & \multicolumn{2}{c|}{$\begin{array}{c}\text { Seedling evaluation (Under screenhouse } \\
\text { conditions) }\end{array}$} \\
\cline { 3 - 5 } & & & PB Severity index(1-5) & PB incidence, \% \\
\hline $\begin{array}{l}\text { Trichoderma harzianum } \\
\text { (T69) }\end{array}$ & Soil & $\begin{array}{l}\text { Over growth or } \\
\text { masking effect }\end{array}$ & $1.68 \mathrm{c}$ & 50.22 \\
\hline T. harzianum (Th) & $\begin{array}{l}\text { Commercial product } \\
\text { (Niprot) }\end{array}$ & ZI $(0.4 \mathrm{~cm})$ & $1.83 \mathrm{bc}$ & 64.06 \\
\hline T. harzianum (T22) & $\begin{array}{l}\text { Commercial product } \\
\text { (PlantShield) }\end{array}$ & ZI $(0.45 \mathrm{~cm})$ & $1.76 \mathrm{bc}$ & 58.87 \\
\hline T. asperellum $(\mathrm{TS})$ & Soil & Not tested & $2.05 \mathrm{ab}$ & 66.69 \\
\hline T. koningii $(\mathrm{TK})$ & NK & $\begin{array}{l}\text { Over growth or } \\
\text { masking effect }\end{array}$ & $1.88 \mathrm{abc}$ & 61.50 \\
\hline Control & - & - & $2.14 \mathrm{a}$ & 65.88 \\
\hline $\begin{array}{l}\text { CV }(\%) \\
\text { P value }\end{array}$ & & & $\begin{array}{l}9.85 \\
0.0204\end{array}$ \\
\hline
\end{tabular}

Means followed by the same letter are not significantly different at $\mathrm{P}=0.05$ by Duncan;s multiple range test. $\mathrm{ZI}=$ zone of inhibition, $\mathrm{NK}=$ not known.

Table 2. Effects of Trichoderma spp. on Phytophthora blight disease of pepper in the field conditions at Luvu, 2012(2069/70)

\begin{tabular}{|c|c|c|c|c|c|}
\hline Treatments & $\begin{array}{l}\text { Dose and method } \\
\text { of application }\end{array}$ & $\begin{array}{c}\text { Mean disease } \\
\text { incidence } \\
\text { percent of } \\
\text { crown/root rot }\end{array}$ & $\begin{array}{c}\text { Reduction } \\
\% \text { in disease } \\
\text { incidence over } \\
\text { control }\end{array}$ & $\begin{array}{c}\text { Mean severity } \\
\text { index of foliar } \\
\text { blight } \\
(1-5)\end{array}$ & $\begin{array}{c}\text { Reduction \% } \\
\text { in severity } \\
\text { index of } \\
\text { foliar blight } \\
\text { over control }\end{array}$ \\
\hline $\begin{array}{l}\text { Trichoderma } \\
\text { harzianum (T69) }\end{array}$ & $\begin{array}{l}* 20 \mathrm{~g} / \text { plant, planting } \\
\text { hole application }\end{array}$ & $27.77 \mathrm{~b}$ & 56.54 & 2.20 & 33.33 \\
\hline T. harzianum (Th) & $\begin{array}{l}* 20 \mathrm{~g} / \text { plant, planting } \\
\text { hole application }\end{array}$ & $34.72 \mathrm{~b}$ & 45.66 & 2.40 & 27.27 \\
\hline T.asperellum (TS) & $\begin{array}{l}* 20 \mathrm{~g} / \text { plant, planting } \\
\text { hole application }\end{array}$ & $50.00 \mathrm{ab}$ & 21.75 & 2.96 & 10.30 \\
\hline T.harzianum (T22) & $\begin{array}{l}* 20 \mathrm{~g} / \text { plant, planting } \\
\text { hole application }\end{array}$ & $34.72 \mathrm{~b}$ & 45.66 & 2.60 & 21.21 \\
\hline Garlic extract & $\begin{array}{l}25 \mathrm{~g} / \text { liter water } \\
\text { drenching } 100 \mathrm{ml} / \\
\text { plant }\end{array}$ & $49.27 \mathrm{ab}$ & 22.89 & 2.20 & 33.3 \\
\hline Fluazinam & $\begin{array}{l}2 \mathrm{~g} / \text { liter water, } \\
\text { drenching } 100 \mathrm{ml} / \\
\text { plant and foliar } \\
\text { spray }\end{array}$ & $37.51 \mathrm{~b}$ & 41.30 & 2.10 & 36.36 \\
\hline Control & - & $63.9 \mathrm{a}$ & -------- & 3.30 & -------- \\
\hline $\begin{array}{l}\text { CV \% } \\
\text { P-value }\end{array}$ & & $\begin{array}{l}21.85 \\
0.0206\end{array}$ & & $\begin{array}{l}11.25 \\
0.2795\end{array}$ & \\
\hline
\end{tabular}

Means followed by the same letter are not significantly different at $\mathrm{P}=0.05$ by Duncan's multiple range test. *Two weeks old Trichoderma culture multiplied in rice husk. 


\begin{tabular}{|c|c|c|c|c|c|}
\hline \multicolumn{6}{|c|}{$2013(2070 / 71)$} \\
\hline Treatments & $\begin{array}{c}\text { Dose and method of } \\
\text { application }\end{array}$ & \begin{tabular}{|} 
Mean disease \\
incidence (DI) \\
percent of \\
crown/root rot
\end{tabular} & $\begin{array}{l}\text { Reduction \% of } \\
\text { DI over control }\end{array}$ & $\begin{array}{l}\text { Mean severity } \\
\text { index of foliar } \\
\text { blight (1-5) }\end{array}$ & $\begin{array}{l}\text { Reduction \% } \\
\text { in severity } \\
\text { index of } \\
\text { foliar blight } \\
\text { over control }\end{array}$ \\
\hline $\begin{array}{l}\text { Trichoderma } \\
\text { harzianum (T69) }\end{array}$ & $\begin{array}{l}* 20 \mathrm{~g} / \text { plant, planting } \\
\text { hole application }\end{array}$ & $44.82 \mathrm{~b}$ & 36.21 & $1.5 \mathrm{bc}$ & 54.54 \\
\hline T. harzianum & $\begin{array}{l}* 20 \mathrm{~g} / \text { plant, planting } \\
\text { hole application }\end{array}$ & $64.02 \mathrm{a}$ & 8.88 & $2.77 \mathrm{a}$ & 16.06 \\
\hline T. asperellum (TS) & $\begin{array}{l}* 20 \mathrm{~g} / \text { plant, planting } \\
\text { hole application }\end{array}$ & $77.77 \mathrm{a}$ & - & $3.1 \mathrm{a}$ & 6.06 \\
\hline$v(\mathrm{~T} 22)$ & $\begin{array}{l}* 20 \mathrm{~g} / \text { plant, planting } \\
\text { hole application }\end{array}$ & $59.07 \mathrm{ab}$ & 15.92 & $2.43 \mathrm{ab}$ & 26.36 \\
\hline $\begin{array}{l}\text { Copper } \\
\text { oxychloride } \\
\text { (Curex) }\end{array}$ & $\begin{array}{l}2 \mathrm{~g} / \text { liter water, } \\
\text { drenching } 100 \mathrm{ml} / \\
\text { plant and foliar spray }\end{array}$ & $37.91 b$ & 46.04 & $1.17 \mathrm{c}$ & 64.54 \\
\hline Fluazinam & $\begin{array}{l}2 \mathrm{~g} / \text { liter water, } \\
\text { drenching } 100 \mathrm{ml} / \\
\text { plant and foliar spray }\end{array}$ & $39.21 \mathrm{~b}$ & 44,19 & $1.56 \mathrm{bc}$ & 52.72 \\
\hline Control & & $70.26 \mathrm{a}$ & -------- & $3.30 \mathrm{a}$ & ------- \\
\hline $\begin{array}{l}\mathrm{CV} \% \\
\text { P-value } \\
\text { LSD }\end{array}$ & & $\begin{array}{l}22.03 \\
0.0065\end{array}$ & & $\begin{array}{l}28.22 \\
0.0184\end{array}$ & \\
\hline
\end{tabular}

Means followed by the same letter are not significantly different at $\mathrm{P}=0.05$ by Duncan;s multiple range test. *Two

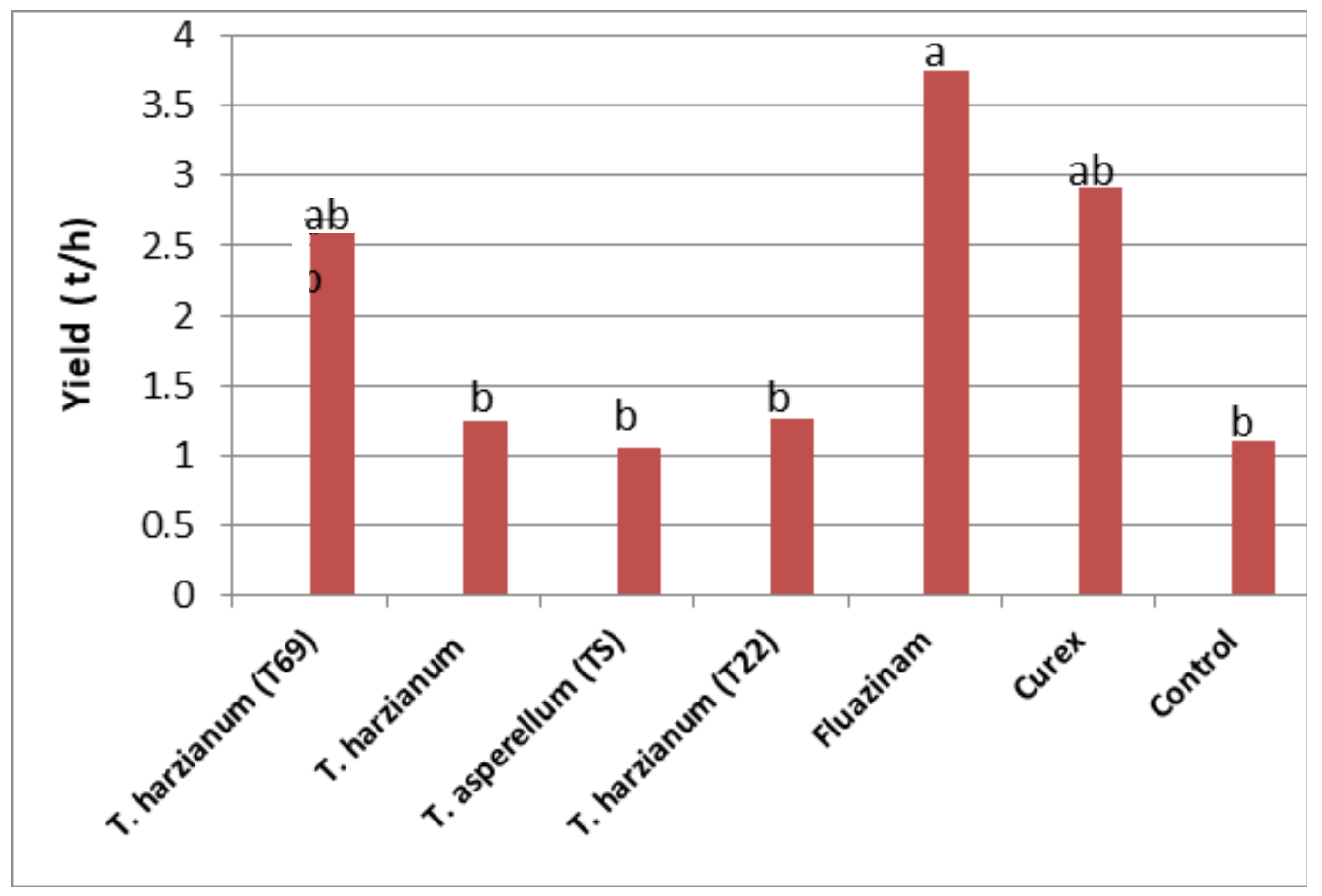

weeks old Trichoderma culture multiplied in rice husk.

Figure 1. Effects of Trichoderma isolates on the yield of chilli at harvest compared to chemical fungicides used against Phytophthora blight at Luvu (2070/71, 2013) (Mean values followed by the same letter are not significantly different at $\mathrm{p}=0.05$ by Duncan's multiple range test, $\mathrm{CV}=58.53 \%$ and $\mathrm{P}$ value $=0.0381$. 


\section{Conclusion}

It is concluded that the tested T. harzianum isolates except $T$. asperellum have biological control efficacy against Phytophthora blight disease. Among the isolates of T. harzianum, the local isolate T69 was the most effective one and comparable to the chemical fungicides, copper oxychloride and fluazinam. Hence, T. harzianum (T69) could be used as one of the effective alternative tools in integrated disease management of Phytophthora blight disease It can be used alone or in combination with copper oxychloride for additive effects.

\section{Acknowledgements}

The authors would like to thank Ms. Pushpa Shrestha and Kamala Shrestha for their valuable assistance in the laboratory and screenhouse works. Thanks are also extended to the farmer for providing field for the experiment.

\section{References}

Ahmed Sid Ahmed, Consuelo Pérez Sánchez and, Maria Emilia Candela, 2000. Evaluation of induction of systemic resistance in pepper plants (Capsicum annuum) to Phytophthora capsici Using Trichoderma harzianum and its relation with capsidiol accumulation. European Journal of Plant Pathlogy.Volume 106, Issue 9, pp 817 824

Barksdale, T. H., G. C. Papavizas, and S. A. Johnston.1984. Resistance to foliar blight and crown rot of pepper caused biological control. Phytopathology 91:621-627.

CABI. 2001. Crop Protection Compendium . CAB International. 2001ISSN 1365-9065, ISBN;085 1995683.

Ezziyyani M., M.E. Requena, C. Egea-Gilabert and M.E. Candela, 2007. Biological control of

Phytophthora root rot of pepper using Trichoderma harzianum and Streptomyces rochei in combination. Journal of Phytopathology 155, $342-349$
Hausbeck, M. K., and Lamour, K. H. 2004.Phytophthora capsici on vegetable crops: Research progress and management challenges. Plant Dis. 88:12921303.

Hwang, B.K. and C.H. Kim. 1995. Phytophthora blight of pepper and its control in Korea. Plant Dis. 79:221-227.

Johnston, S. A. 1997. Phytophthora management.In proceedings. New England Vegetable and Berry conference and Trade Show. Dec.16-18, 1997. Sturbridge, Massachusetts

Khetan, S.K. 2001.Microbial pestcontrol. Marcel Dekker, Inc.300pp.

Knudsen, G. R. and L. C. Dandurand. 2014. Ecological complexity and the success of fungal biological control agents. Advances in Agriculture Volume 2014 (2014), Article ID 542703, 11 pages

PPD, 2012.Annual Report FY 2067-68 (2010-2011). Plant Pathology Division, NARC.

PPD, 2014.Annual Report 2070/71(2013/14) Plant Pathology Division, NARC.

Ristaino, J.B.1991. Influence of rainfall, drip irrigation and inoculums density on the development of phytphthora root and crown rot epidemics and yield.in bell pepper. Phytopathology 81:922929.

Segarra,G., M.avilés, E.Casanova, C.Borrero and I. Trillas 2013. Effectiveness of biological control of Phytophthora capsici in pepper by Trichoderma asperellum strain T34. .Phytopathologia Mediterranea(2013) 52, 1, 77-83

Staff, Agdaily. 2018. The list of organic pesticides approved by the USDA. https://www.agdaily. com/technology/the-list-of-pesticides-approvedfor-organic-productio/

Tian, D. and M. Babadoost.2004.Host range of Phytophthora capsici from pumpkin and pathogenecity of isolates.Plant Dis.88.485-489. 